This document was prepared in conjunction with work accomplished under Contract No. DE-AC09-96SR18500 with the U.S. Department of Energy.

This work was prepared under an agreement with and funded by the U.S. Government. Neither the U. S. Government or its employees, nor any of its contractors, subcontractors or their employees, makes any express or implied: 1 . warranty or assumes any legal liability for the accuracy, completeness, or for the use or results of such use of any information, product, or process disclosed; or 2 . representation that such use or results of such use would not infringe privately owned rights; or 3 . endorsement or recommendation of any specifically identified commercial product, process, or service. Any views and opinions of authors expressed in this work do not necessarily state or reflect those of the United States Government, or its contractors, or subcontractors. 
WSRC-STI-2007-00285

Revision 0

\section{Dissolution of Fissile Materials Containing Tantalum Metal}

\section{Tracy S. Rudisill, Mark L. Crowder, and Michael G. Bronikowski}

May 2007

Washington Savannah River Company

Aiken, SC 29808 

WSRC-STI-2007-00285

Revision 0

\title{
Dissolution of Fissile Materials Containing Tantalum Metal
}

By

\author{
Tracy S. Rudisill, Mark L. Crowder, and Michael G. Bronikowski \\ Issued: May 2007
}

\section{Approvals}

Tracy S. Rudisill, Author

Date

Mark L. Crowder, Author

Date

Michael G. Bronikowski, Author

Date

Samuel D. Fink, Manager / Separations Science Programs

Date

Alice M. Murray, Manager / Actinide and Chemical Technology Date

George J. Zachmann III, Manager / HB-Line Engineering

Date

Robert A. Pierce, Technical Reviewer, Actinide and Chemical Technology Date

Rosa D. Hill, Technical Reviewer, HB-Line Engineering

Date 
Revision 0

\section{This page was intentionally left blank.}




\section{Table of Contents}

Section $\quad$ Page

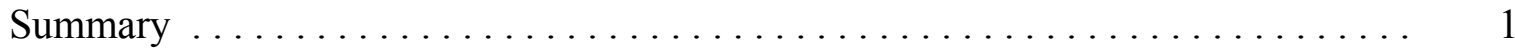

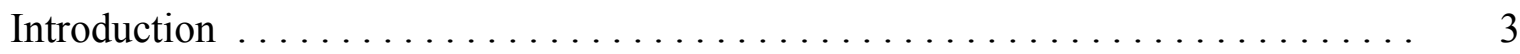

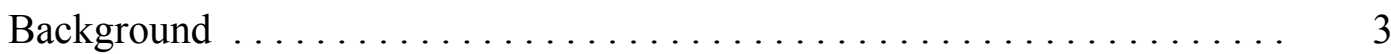

Experimental Objectives $\ldots \ldots \ldots \ldots \ldots \ldots \ldots \ldots \ldots \ldots \ldots \ldots$

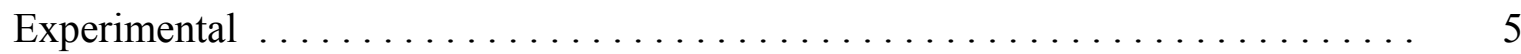

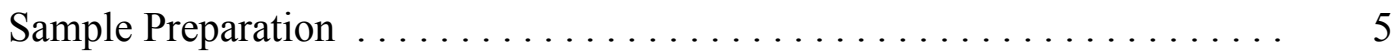

Dissolution Experiments $\ldots \ldots \ldots \ldots \ldots \ldots \ldots \ldots \ldots \ldots \ldots$

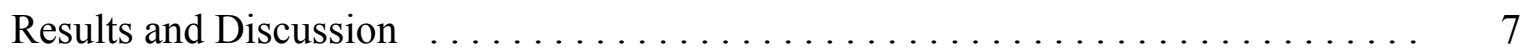

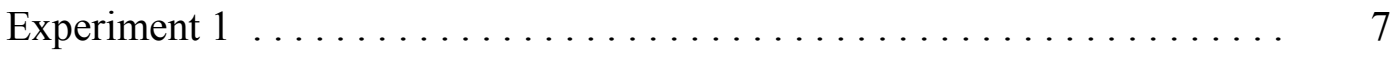

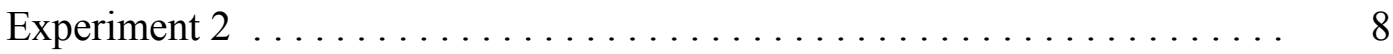

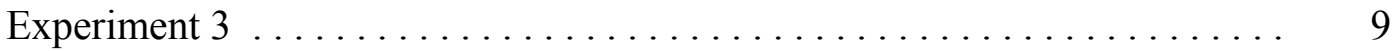

Offgas Analyses $\ldots \ldots \ldots \ldots \ldots \ldots \ldots \ldots \ldots \ldots \ldots \ldots \ldots \ldots \ldots \ldots \ldots$

Trace Metal Analyses . . . . . . . . . . . . . . . . . . . . . 12

Acid Analyses $\ldots \ldots \ldots \ldots \ldots \ldots \ldots \ldots \ldots \ldots \ldots \ldots \ldots \ldots \ldots \ldots \ldots$

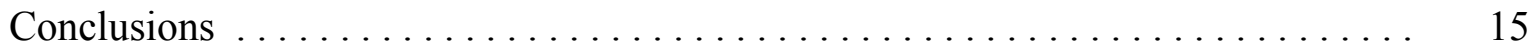

Flowsheet Recommendations $\ldots \ldots \ldots \ldots \ldots \ldots \ldots \ldots \ldots \ldots \ldots \ldots \ldots$

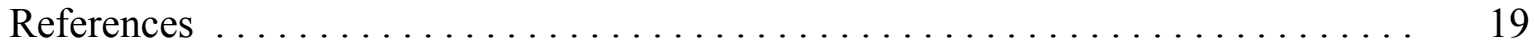




\section{List of Tables}

\section{Page}

Table $1 \quad$ Mass of Composite Material Samples $\ldots \ldots \ldots \ldots \ldots \ldots \ldots \ldots$

Table 2 Comparison of Conditions for Dissolution of $\mathrm{Pu} / \mathrm{Ta} \ldots \ldots \ldots$ Composite Materials

Table $3 \quad \mathrm{Pu}$ Solution Analyses for Experiment $1 \ldots \ldots \ldots \ldots \ldots$

Table $4 \quad$ Pu Solution Analyses for Experiment $2 \ldots \ldots \ldots \ldots$

Table $5 \quad$ Pu Solution Analyses for Experiment $3 \ldots \ldots \ldots \ldots \ldots \ldots \ldots$

Table $6 \quad$ Gas Generation During Pu/Ta Dissolution Experiments $\ldots \ldots \ldots \ldots 11$

Table $7 \quad$ Trace Metal Analyses for $\mathrm{Pu} / \mathrm{Ta}$ Composite Dissolutions $\ldots \ldots \ldots$

Table $8 \quad$ Acid Analyses for $\mathrm{Pu} / \mathrm{Ta}$ Dissolution Experiments $\ldots \ldots \ldots \ldots$

\section{List of Figures}

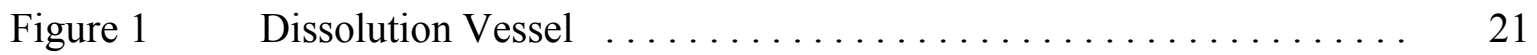

Figure 2 Three-neck Flask Dissolving System and Glass Basket . . . . . . 23

Figure 3 Dissolution of Composite Materials Containing $\mathrm{Pu}$ and $\ldots \ldots \ldots 25$ Ta Metals

\section{List of Appendices}

Appendix A Plutonium Analyses for $\mathrm{Pu} / \mathrm{Ta}$ Composite Material . . . . . . . . . 27 Dissolutions

Appendix B Calculation of Adjusted $\mathrm{H}_{2}$ Concentration and Gas. . . . . . . . . 31 Generation Rate 
WSRC-STI-2007-00285

Revision 0

\title{
Dissolution of Fissile Materials Containing Tantalum Metals
}

\author{
Tracy S. Rudisill, Mark L. Crowder, and M. G. Bronikowski \\ Washington Savannah River Company \\ Aiken, SC 29808
}

\section{Summary}

The dissolution of composite materials containing plutonium $(\mathrm{Pu})$ and tantalum $(\mathrm{Ta})$ metals is currently performed in Phase I of the HB-Line facility. The conditions for the present flowsheet are the dissolution of $500 \mathrm{~g}$ of $\mathrm{Pu}$ metal in the $15 \mathrm{~L}$ dissolver using a $4 \mathrm{M}$ nitric acid $\left(\mathrm{HNO}_{3}\right)$ solution containing $0.2 \mathrm{M}$ potassium fluoride (KF) at $95^{\circ} \mathrm{C}$ for $4-6 \mathrm{~h}$.[1] The Ta metal, which is essentially insoluble in $\mathrm{HNO}_{3}$ /fluoride solutions, is rinsed with process water to remove residual acid, and then burned to destroy classified information. During the initial dissolution campaign, the total mass of $\mathrm{Pu}$ and $\mathrm{Ta}$ in the dissolver charge was limited to nominally $300 \mathrm{~g}$. The reduced amount of $\mathrm{Pu}$ in the dissolver charge coupled with significant evaporation of solution during processing of several dissolver charges resulted in the precipitation of a fluoride salt contain $\mathrm{Pu}$. Dissolution of the salt required the addition of aluminum nitrate $\left(\mathrm{Al}\left(\mathrm{NO}_{3}\right)_{3}\right)$ and a subsequent undesired $4 \mathrm{~h}$ heating cycle. As a result of this issue, HB-Line Engineering requested the Savannah River National Laboratory (SRNL) to optimize the dissolution flowsheet to reduce the cycle time, reduce the risk of precipitating solids, and obtain hydrogen $\left(\mathrm{H}_{2}\right)$ generation data at lower fluoride concentrations.[2]

Using samples of the $\mathrm{Pu} / \mathrm{Ta}$ composite material, we performed three experiments to demonstrate the dissolution of the $\mathrm{Pu}$ metal using $\mathrm{HNO}_{3}$ solutions containing 0.15 and $0.175 \mathrm{M} \mathrm{KF}$. When $0.15 \mathrm{M} \mathrm{KF}$ was used in the dissolving solution, $95.5 \%$ of the $\mathrm{Pu}$ in the sample dissolved in approximately $6 \mathrm{~h}$. The undissolved material included a small amount of Pu metal and plutonium oxide $\left(\mathrm{PuO}_{2}\right)$ solids. Complete dissolution of the metal would have likely occurred if the dissolution time had been extended. This assumption is based on the steady increase in the $\mathrm{Pu}$ concentration observed during the last several hours of the experiment. We attribute the formation of $\mathrm{PuO}_{2}$ to the complexation of fluoride by the $\mathrm{Pu}$. The fluoride became unavailable to catalyze the dissolution of $\mathrm{PuO}_{2}$ as it formed on the surface of the metal. The mass of $\mathrm{Pu}$ dissolved is equivalent to the dissolution of $343 \mathrm{~g}$ of $\mathrm{Pu}$ in the HB-Line dissolvers.

In the initial experiment with $0.175 \mathrm{M} \mathrm{KF}$ in the solution, we achieved complete dissolution of the $\mathrm{Pu}$ in $6 \mathrm{~h}$. The mass of $\mathrm{Pu}$ dissolved scales to the dissolution of $358 \mathrm{~g}$ of $\mathrm{Pu}$ in the HB-Line dissolvers. The second experiment using $0.175 \mathrm{M} \mathrm{KF}$ was terminated after approximately $6 \mathrm{~h}$ following the dissolution of $92.7 \%$ of the $\mathrm{Pu}$ in the sample; however, dissolution of additional $\mathrm{Pu}$ was severely limited due to the slow dissolution rate observed beyond approximately $4 \mathrm{~h}$. A small amount of $\mathrm{PuO}_{2}$ was also produced in the solution. The slow rate of dissolution was attributed to the diminishing surface area of the $\mathrm{Pu}$ and a reduction in the fluoride activity due to complexation with $\mathrm{Pu}$. Given time $(>4 \mathrm{~h}$ ), the $\mathrm{Pu}$ metal may have dissolved using the original solution or a significant portion may have oxidized to $\mathrm{PuO}_{2}$. If the metal oxidized to $\mathrm{PuO}_{2}$, we 
expect little of the material would have dissolved due to the fluoride complexation and the low $\mathrm{HNO}_{3}$ concentration. The mass of $\mathrm{Pu}$ dissolved in the second experiment scales to the dissolution of $309 \mathrm{~g}$ of $\mathrm{Pu}$ in the HB-Line dissolvers.

Based on the data from the $\mathrm{Pu} / \mathrm{Ta}$ dissolution experiments we recommend the use of $4 \mathrm{M} \mathrm{HNO}_{3}$ containing $0.175 \mathrm{M} \mathrm{KF}$ for the dissolution of $300 \mathrm{~g}$ of Pu metal in the $15 \mathrm{~L}$ HB-Line dissolver. A dissolution temperature of nominally $95{ }^{\circ} \mathrm{C}$ should allow for essentially complete dissolution of the metal in $6 \mathrm{~h}$. Although the $\mathrm{H}_{2}$ concentration in the offgas from the experiments was at or below the detection limit of the gas chromatograph (GC) used in these experiments, small concentrations ( $<3 \mathrm{vol} \%$ ) of $\mathrm{H}_{2}$ are typically produced in the offgas during Pu metal dissolutions. Therefore, appropriate controls must be established to address the small $\mathrm{H}_{2}$ generation rates in accordance with this work and the earlier flowsheet demonstrated for $\mathrm{Pu}$ metal.[3] 


\section{Introduction}

\section{$\underline{\text { Background }}$}

Scrap materials containing Pu metal are currently dissolved in Phase I of HB-Line for subsequent disposition through the H-Canyon facility. Some of the materials scheduled for disposition in the near future are composite materials containing Pu and Ta metals. Since Ta metal is essentially insoluble in $\mathrm{HNO}_{3}$ /fluoride solutions, the preferred approach for handling this material is to dissolve the $\mathrm{Pu}$ metal, rinse the Ta metal with process water to remove residual acid, and then burn the Ta metal. The use of a $4 \mathrm{M} \mathrm{HNO}_{3}$ solution containing $0.2 \mathrm{M}$ fluoride at $70{ }^{\circ} \mathrm{C}$ for $10 \mathrm{~h}$ followed by $4 \mathrm{~h}$ at $95^{\circ} \mathrm{C}$ was initially recommended for the dissolution of approximately $500 \mathrm{~g}$ of Pu metal.[4] However, prior to the use of the flowsheet in the HB-Line facility, a new processing plan was proposed in which the feed to the HB-Line dissolver could contain up to $1250 \mathrm{~g}$ of $\mathrm{Pu}$ metal.

Due to the potential increase in the mass of $\mathrm{Pu}$ metal associated with the composite material, a scaled laboratory demonstration was performed to evaluate the effects of increasing the batch size. A dissolution was performed using a mass of $\mathrm{Pu}$ metal and a solution volume based on the proposed batch size and the HB-Line dissolver volume. In the experiment, nominally $45 \%$ of $\mathrm{Pu}$ dissolved in $4 \mathrm{~h}$. The remaining metal used in the experiment was converted to $\mathrm{PuO}_{2}$. The concentrations of $\mathrm{Pu}$ in the dissolving solution were essentially identical at 4 and $8 \mathrm{~h}$, indicating that a cycle time longer than about $4 \mathrm{~h}$ did not result in the dissolution of additional $\mathrm{Pu}$. When the fluoride concentration was increased to approximately $0.3 \mathrm{M}$, the Pu concentration decreased by $33 \%$. The decrease in the $\mathrm{Pu}$ concentration was attributed to the precipitation of a $\mathrm{Pu}$ fluoride compound. Based on that work, the use of a $4 \mathrm{M} \mathrm{HNO}_{3}$ solution containing $0.2 \mathrm{M} \mathrm{KF}$ at $95{ }^{\circ} \mathrm{C}$ for 4-6 h was recommended for the dissolution of approximately $500 \mathrm{~g}$ of Pu metal in the HBLine dissolver.[1]

During the initial dissolution campaign, the total amount of $\mathrm{Pu}$ and $\mathrm{Ta}$ in the dissolver charge was limited to nominally $300 \mathrm{~g}$ based on nuclear safety constraints. The smaller mass of $\mathrm{Pu}$ (which increased the fluoride to Pu ratio) coupled with significant evaporation of solution during several dissolver runs resulted in the precipitation of a double fluoride salt of potassium $(\mathrm{K})$ and $\mathrm{Pu}\left(\mathrm{KPu}_{2} \mathrm{~F}_{9}\right)$. The precipitation of the double salt had been observed in a $27 \mathrm{~g} / \mathrm{L} \mathrm{Pu}$ solution containing a total fluoride concentration between 0.26 and $0.28 \mathrm{M}$ during previous flowsheet development activities.[5] Dissolution of the salt in the HB-Line dissolver required the addition of $\mathrm{Al}\left(\mathrm{NO}_{3}\right)_{3}$ and subsequent heating for $4 \mathrm{~h}$, a lengthy and undesired processing step. 


\section{Experimental Objectives}

As a result of the difficulties associated with the dissolution of the $\mathrm{Pu} / \mathrm{Ta}$ composite material, HB-Line Engineering requested SRNL to optimize the flowsheet to reduce the risk of precipitating solids, reduce the cycle time, and obtain $\mathrm{H}_{2}$ generation data at lower fluoride concentrations (e.g., $0.15 \mathrm{M}$ ). A $42 \mathrm{~g}$ sample of the Pu/Ta composite material from HB-Line was transferred to SRNL on January 3, 2007 for use in the flowsheet optimization. Three dissolution experiments were performed. Descriptions of the experiments, a discussion of the observations and analytical data, conclusions, and flowsheet recommendations are presented in the following sections. 


\section{Experimental}

\section{Sample Preparation}

A $42.36 \mathrm{~g}$ sample of the $\mathrm{Pu} / \mathrm{Ta}$ composite material was obtained from HB-Line. The nondestructive assay for the sample indicated that it contained $28.30 \mathrm{~g}$ of $\mathrm{Pu}$. We cut the sample into three pieces in preparation for three dissolution experiments. Each of the pieces contained both $\mathrm{Pu}$ and Ta metal. We calculated the amount of $\mathrm{Pu}$ associated with each piece based on the estimated surface area of the samples assuming a uniform thickness of the Pu metal. The estimated fraction of the total sample surface area and the bulk and estimated $\mathrm{Pu}$ masses of each piece are given in Table 1.

Table 1 Mass of Composite Material Samples

\begin{tabular}{cccc}
\hline \hline $\begin{array}{c}\text { Sample ID } \\
\text { Identification }\end{array}$ & $\begin{array}{c}\text { Bulk } \\
\text { Mass } \\
(\mathrm{g})\end{array}$ & $\begin{array}{c}\text { Fraction of } \\
\text { Surface Area }\end{array}$ & $\begin{array}{c}\text { Estimated Pu } \\
\text { Mass } \\
(\mathrm{g})\end{array}$ \\
\hline $\mathrm{A}$ & 24.99 & 0.50 & 14.15 \\
$\mathrm{~B}$ & 9.04 & 0.25 & 7.08 \\
$\mathrm{C}$ & 8.33 & 0.25 & 7.08 \\
\hline
\end{tabular}

\section{$\underline{\text { Dissolution Experiments }}$}

Three experiments were performed to optimize the flowsheet for the dissolution of the $\mathrm{Pu} / \mathrm{Ta}$ composite material in the HB-Line facility. The existing flowsheet is based on the use of a $4 \mathrm{M}$ $\mathrm{HNO}_{3} / 0.2 \mathrm{M} \mathrm{KF}$ solution in the $15 \mathrm{~L} \mathrm{HB}$-Line dissolver.[1] We based the solid-to-liquid ratio for the initial experiment on the dissolution of $500 \mathrm{~g}$ of $\mathrm{Pu}$ metal in the $15 \mathrm{~L}$ dissolver to maximize the potential HB-Line throughput.[2] The volume of solution used in the experiment was determined by assuming the charge was $100 \%$ Pu metal and using the estimated Pu mass of the sample piece to scale the HB-Line dissolver volume. In the subsequent experiments, the same total sample mass-to-liquid ratio was maintained although we increased the fluoride concentration of the solution in Experiments 2 and 3 from 0.15 to $0.175 \mathrm{M}$. The motivation for the increased fluoride concentration is discussed in the following section. Table 2 provides a comparison of the existing HB-Line flowsheet and the conditions used in each dissolution experiment.

Table 2 Comparison of Conditions for Dissolution of $\mathrm{Pu} / \mathrm{Ta}$ Composite Materials

\begin{tabular}{lccccc}
\hline \hline Flowsheet & \multicolumn{2}{c}{ Dissolving Solution } & \multicolumn{2}{c}{ Liquid } & \multicolumn{2}{c}{ Charge/Sample Mass } \\
& $\mathrm{HNO}_{3}$ & $\mathrm{KF}$ & Volume & Total & $\mathrm{Pu}$ \\
& $(\mathrm{M})$ & $(\mathrm{M})$ & $(\mathrm{L})$ & $(\mathrm{g})$ & $(\mathrm{g})$ \\
\hline HB-Line & 4 & 0.2 & 15 & 500 & 500 \\
Exp. 1 & 4 & 0.15 & 0.210 & 9.04 & $7.08^{(1)}$ \\
Exp. 2 & 4 & 0.175 & 0.194 & 8.33 & $7.08^{(1)}$ \\
Exp. 3 & 4 & 0.175 & 0.580 & 24.99 & $14.15^{(1)}$ \\
\hline
\end{tabular}

(1) Estimated mass of Pu. 
To perform Experiments 1 and 2, we used a small $(250 \mathrm{~mL})$ glass vessel fitted with a watercooled condenser as the dissolver (Figure 1). The vessel was heated and stirred using a hot plate equipped with a magnetic stirrer. A thermocouple probe connected to the hot plate was used for temperature control. The accuracy of the probe was verified using a calibrated thermometer. In Experiment 3, the larger solution volume required the use of a $1 \mathrm{~L}$ flask as the dissolver (Figure 2). We heated and stirred the flask using a heating mantle equipped with a magnetic stirrer. The temperature was manually controlled by observing the calibrated thermometer and adjusting the set point of the heating mantle. In each experiment, the temperature of the dissolving solution was maintained at $90-100{ }^{\circ} \mathrm{C}$ for 5-6 h. We periodically removed solution samples from the dissolver and sampled the solution when the dissolution was terminated. In Experiments 1 and 3 , it was also necessary to dissolve a small amount of Pu metal which was not completely removed from the Ta metal during the initial dissolution as well as solids recovered from the solution. The dissolution of these materials is discussed in the following section.

During each experiment, we measured the volume of offgas and collected samples for $\mathrm{H}_{2}$ analyses. The gas and solution samples were collected at the same time. To sample and collect the offgas, the exit from the condenser on either dissolver was connected with plastic tubing to $25 \mathrm{~mL}$ sample bulbs and $1 \mathrm{~L}$ Tedlar ${ }^{\mathrm{TM}}$ bags. The sample bulbs were fabricated with glass stopcocks on the ends to provide a means to isolate the sample. Quick disconnects (which seal upon disconnection) were used to attach and remove the sample bulbs and Tedlar ${ }^{\mathrm{TM}}$ bags from the plastic tubing. The total volume of gas generated during the dissolution was collected. The sample bulbs and Tedlar ${ }^{\mathrm{TM}}$ bags were simultaneously removed from the dissolving system. We measured the volume of gas collected during the dissolutions by measuring the difference in the amount of water displaced by the empty (evacuated) and filled bags. Gas analyses were performed using a GC. The ${ }^{239} \mathrm{Pu}$ concentration in the samples was measured by gamma pulse height analysis (GPHA). The total $\mathrm{Pu}$ concentration was calculated by assuming the metal is weapons grade material (i.e., $94 \%{ }^{239} \mathrm{Pu}$ and $6 \%{ }^{240} \mathrm{Pu}$ ). A sample of the solution was also analyzed for selected trace elements using Inductively Coupled Plasma Emission Spectroscopy (ICP-ES), Atomic Absorption Spectroscopy (AAS), and Cold Vapor (CV) AAS. Total and free acid were measured by titration. 


\section{Results and Discussion}

\section{Experiment 1}

\section{Observations}

Since $\mathrm{Pu}$ metal dissolution experiments were previously performed using $4 \mathrm{M} \mathrm{HNO}_{3}$ solutions containing 0.1 and $0.2 \mathrm{M} \mathrm{KF},[1,3]$ we chose to use a KF concentration of $0.15 \mathrm{M}$ in the initial experiment. When the $\mathrm{Pu} / \mathrm{Ta}$ composite material was added to the dissolving solution, we initially observed the formation of a blue color characteristic of a $\mathrm{Pu}^{3+}$ nitrate solution. Subsequently, the solution turned brown as the $\mathrm{Pu}$ oxidized to $\mathrm{Pu}^{4+}$. Throughout the dissolution, the sample generated small bubbles of gas. The bubbles originated from the bottom of the sample which indicated the Pu metal side of the material faced downward and was in contact with the bottom of the vessel. The orientation of the sample may have reduced the rate at which the $\mathrm{Pu}$ metal dissolved. The presence of nitrogen dioxide $\left(\mathrm{NO}_{2}\right)$ gas in the sample bulbs and Tedlar ${ }^{\mathrm{TM}}$ bags was confirmed by the brown color. Prior to removing the first gas sample, a small leak at the ground glass joint between the dissolving vessel and condenser was observed and corrected; therefore, the volume of gas collected and the first gas sample are not completely representative of this dissolution period.

We encountered some difficulty heating the solution to the desired temperature due to a poor thermocouple connection which controlled the hot plate; however, we were able to heat the solution for approximately $5 \mathrm{~h}$ at a temperature between 85 and $95{ }^{\circ} \mathrm{C}$. When the experiment was terminated and the remaining sample was inspected, we concluded that the Pu metal did not completely dissolve. The mass of the sample following the initial dissolution was $4.037 \mathrm{~g}$. To dissolve the remaining Pu metal, we subsequently placed the sample in approximately $35 \mathrm{~mL}$ of an $8 \mathrm{M} \mathrm{HNO}_{3}$ solution containing $0.15 \mathrm{M} \mathrm{KF}$. Complete dissolution of the remaining Pu metal required approximately $2.5 \mathrm{~h}$. The mass of the Ta metal was $3.866 \mathrm{~g}$. It was also necessary to dissolve a small amount of $\mathrm{PuO}_{2}$ solids recovered from the original solution. The solids were isolated by filtration and dissolved using approximately $70 \mathrm{~mL}$ of a solution containing $8 \mathrm{M}$ $\mathrm{HNO}_{3} / 0.15 \mathrm{M} \mathrm{KF}$. The $\mathrm{PuO}_{2}$ required less than $1 \mathrm{~h}$ for complete dissolution.

\section{Plutonium Analyses}

The Pu solution analyses for Experiment 1 are summarized in Table 3. The one sigma uncertainties associated with the analyses are $\pm 5-10 \%$.

Table $3 \mathrm{Pu}$ Solution Analyses for Experiment 1

\begin{tabular}{cccccc}
\hline \hline $\begin{array}{c}\text { Sample } \\
\text { No. }\end{array}$ & $\begin{array}{c}\text { Cumulative } \\
\text { Time } \\
(\mathrm{h})\end{array}$ & $\begin{array}{c}\mathrm{Pu} \\
\text { Concentration } \\
(\mathrm{g} / \mathrm{L})\end{array}$ & $\begin{array}{c}\text { Estimated } \\
\text { Volume } \\
(\mathrm{mL})\end{array}$ & $\begin{array}{c}\text { Pu } \\
\text { Dissolved } \\
(\%)\end{array}$ & $\begin{array}{c}\text { HB-Line } \\
\text { Basis } \\
(\mathrm{g})\end{array}$ \\
\hline 1 & 2.08 & 13.7 & 210.0 & 57.5 & 206 \\
2 & 4.08 & 17.7 & 209.5 & 73.8 & 265 \\
3 & 6.08 & 22.9 & 209.0 & 95.5 & 343 \\
\hline
\end{tabular}


To calculate the amount of Pu metal dissolved as a function of time, we estimated the volume of solution at each sample time using the initial volume of solution, the volume of samples removed, and the measured volume $(206 \mathrm{~mL})$ following termination of the experiment. The volume of solution evaporated during the experiment was insignificant. We then used the measured $\mathrm{Pu}$ concentration and estimated volume to calculate the mass of $\mathrm{Pu}$ in solution (Appendix A). The calculated mass is expressed as a percentage of the total mass of $\mathrm{Pu}$ dissolved which includes the initial $\mathrm{Pu}$ metal (4.79 g), residual Pu metal (0.15 g), and the $\mathrm{PuO}_{2}$ solids $(0.07 \mathrm{~g})$. The mass of $\mathrm{Pu}$ dissolved as a function of time shows that $>95 \%$ of the total $\mathrm{Pu}$ dissolved during the $6.08 \mathrm{~h}$ dissolution cycle. It should be noted that the solution was only heated to a temperature greater than $85^{\circ} \mathrm{C}$ for approximately $5 \mathrm{~h}$ due to problems with the hot plate thermocouple. Table 3 also provides an estimate of the mass of $\mathrm{Pu}$ which would dissolve in the HB-Line dissolvers using the solution volume to scale the mass of $\mathrm{Pu}$ dissolved during the experiment. The mass of $\mathrm{Pu}$ dissolved in $6.08 \mathrm{~h}(4.79 \mathrm{~g})$ scales to the dissolution of $343 \mathrm{~g} \mathrm{of} \mathrm{Pu}$ in the HB-Line dissolvers.

We speculate that most of the Pu metal remaining on the Ta substrate would have dissolved if the dissolution time had been extended. This assumption is based on the steady increase in the $\mathrm{Pu}$ concentration observed during the last several hours of the dissolution experiment (Figure 3). It is doubtful that the $\mathrm{PuO}_{2}$ formed during the dissolution would have dissolved. Incomplete dissolution of the $\mathrm{PuO}_{2}$ is not a solubility limitation. Plutonium oxide has been successfully dissolved using 12-14 $\mathrm{M} \mathrm{HNO}_{3}$ containing 0.1-0.2 $\mathrm{M}$ fluoride to $\mathrm{Pu}$ concentrations which were greater than $100 \mathrm{~g} / \mathrm{L}$.[6-7] A combination of low acidity and complexation of fluoride by the soluble $\mathrm{Pu}$ slowed the dissolution kinetics of the $\mathrm{PuO}_{2}$ and effectively limited the mass which dissolved.

\section{Experiment 2}

\section{Observations}

Since complete dissolution of the Pu metal associated with the composite material was not achieved in Experiment 1, we chose to increase the fluoride concentration to $0.175 \mathrm{M}$. The higher fluoride concentration increases the rate of Pu metal dissolution. The sample mass-toliquid volume ratio used in this experiment was maintained at the same value as used in Experiment 1. During the dissolution, we observed essentially the same behavior as seen in the initial experiment. The solution originally turned a blue color which transitioned to brown as $\mathrm{Pu}^{3+}$ oxidized to $\mathrm{Pu}^{4+}$. Small bubbles of gas were generated at the top surface of the metal. We concluded that the $\mathrm{Pu}$ metal side of the material was face-up in this experiment based on the origination of the bubbles. The presence of $\mathrm{NO}_{2}$ in the offgas was evident based on the brown color of the gas in the sample bulbs and Tedlar ${ }^{\mathrm{TM}}$ bags. Following approximately $6 \mathrm{~h}$ at a temperature of $90-100^{\circ} \mathrm{C}$, the sample was removed from the dissolver and inspected. We concluded that the Pu metal had completely dissolved based on the visual observation and terminated the experiment. The mass of the Ta metal was $3.749 \mathrm{~g}$. No solids were observed in the dissolution vessel when the dissolution was terminated. Filtration of the solution confirmed that complete dissolution of the $\mathrm{Pu}$ metal had occurred without the generation of $\mathrm{PuO}_{2}$. 


\section{Plutonium Analyses}

The Pu solution analyses for Experiment 2 are summarized in Table 4. The one sigma uncertainties associated with the analyses are $\pm 5-10 \%$.

Table $4 \mathrm{Pu}$ Solution Analyses for Experiment 2

\begin{tabular}{cccccc}
\hline \hline $\begin{array}{c}\text { Sample } \\
\text { No. }\end{array}$ & $\begin{array}{c}\text { Cumulative } \\
\text { Time } \\
(\mathrm{h})\end{array}$ & $\begin{array}{c}\mathrm{Pu} \\
\text { Concentration } \\
(\mathrm{g} / \mathrm{L})\end{array}$ & $\begin{array}{c}\text { Estimated } \\
\text { Volume } \\
(\mathrm{mL})\end{array}$ & $\begin{array}{c}\text { Pu } \\
\text { Dissolved } \\
(\%)\end{array}$ & $\begin{array}{c}\text { HB-Line } \\
\text { Basis } \\
(\mathrm{g})\end{array}$ \\
\hline 1 & 1.97 & 17.4 & 190.7 & 76.0 & 261 \\
2 & 3.99 & 18.0 & 186.9 & 77.1 & 271 \\
3 & 6.02 & 23.9 & 183.0 & 100.0 & 358 \\
\hline
\end{tabular}

To calculate the amount of Pu metal dissolved as a function of time, we followed the same procedure used in Experiment 1, estimating the volume of solution at each sample time using the initial volume of solution, the volume of samples removed, and the measured volume $(180 \mathrm{~mL})$ following termination of the experiment. The volume of solution evaporated during the experiment was estimated at $10.0 \mathrm{~mL}$. We assumed a constant evaporation rate. We used the measured $\mathrm{Pu}$ concentration and estimated volume to calculate the mass of $\mathrm{Pu}$ in solution (Appendix A). The calculated mass is expressed as a percentage of the total mass of $\mathrm{Pu}$ dissolved in Table 4. Complete dissolution of the Pu metal was achieved in $6.02 \mathrm{~h}$. Table 4 also provides an estimate of the mass of $\mathrm{Pu}$ which would be dissolved in the HB-Line dissolvers using the solution volume to scale the mass of $\mathrm{Pu}$ dissolved during the experiment. The mass of $\mathrm{Pu}$ dissolved in $6.02 \mathrm{~h}(4.37 \mathrm{~g})$ scales to the dissolution of $358 \mathrm{~g}$ of $\mathrm{Pu}$ in the HB-Line dissolvers.

\section{Experiment 3}

\section{Observations}

Experiment 3 was designed as a duplication of the second experiment except that it was performed at a larger scale. The larger scale required the use of a $1 \mathrm{~L}$ dissolving vessel to maintain the same mass-to-liquid volume ratio used in the first two experiments. With the larger vessel, we were able to use a glass basket (Figure 2) to suspend the sample in the solution. Visual observations during the dissolution were generally the same as in the previous two experiments. Following approximately $6 \mathrm{~h}$ of heating between 95 and $100^{\circ} \mathrm{C}$, we removed the sample from the vessel for inspection. It appeared that the Pu metal had dissolved; however, a bead of material which was thought to be part of a weld was observed on the surface of the Ta metal. The experiment was terminated based on this interpretation, but we decided to continue the dissolution at a latter date to ensure that the Pu metal had completely dissolved. The mass of the remaining sample (including the bead of material) was $11.771 \mathrm{~g}$.

The Ta metal substrate was subsequently leached using approximately $125 \mathrm{~mL}$ of a $4 \mathrm{M} \mathrm{HNO}_{3}$ solution containing $0.175 \mathrm{M} \mathrm{KF}$. When placed in the solution, it was apparent that the sample still contained $\mathrm{Pu}$ metal. Small gas bubbles were generated at the metal surface and the solution color transitioned from blue to brown. After heating the solution for $3.5 \mathrm{~h}$ at $95-100{ }^{\circ} \mathrm{C}$, the 
metal completely dissolved. Both sides of the Ta substrate were clean. The mass of the Ta metal was $10.886 \mathrm{~g}$. It was also necessary to dissolve a small amount of $\mathrm{PuO}_{2}$ solids recovered from the original dissolving solution. We isolated the solids by filtration and dissolved them in approximately $100 \mathrm{~mL}$ of an $8 \mathrm{M} \mathrm{HNO}_{3} / 0.15 \mathrm{M} \mathrm{KF}$ solution. The mass of the solids was not measured prior to the dissolution. The solids easily dissolved in less than $1 \mathrm{~h}$ when heated to $90{ }^{\circ} \mathrm{C}$.

\section{Plutonium Analyses}

The Pu solution analyses for Experiment 3 are summarized in Table 5. The one sigma uncertainties associated with the analyses are $\pm 5-10 \%$.

Table $5 \mathrm{Pu}$ Solution Analyses for Experiment 3

\begin{tabular}{cccccc}
\hline \hline $\begin{array}{c}\text { Sample } \\
\text { No. }\end{array}$ & $\begin{array}{c}\text { Cumulative } \\
\text { Time } \\
(\mathrm{h})\end{array}$ & $\begin{array}{c}\mathrm{Pu} \\
\text { Concentration } \\
(\mathrm{g} / \mathrm{L})\end{array}$ & $\begin{array}{c}\text { Estimated } \\
\text { Volume } \\
(\mathrm{mL})\end{array}$ & $\begin{array}{c}\text { Pu } \\
\text { Dissolved } \\
(\%)\end{array}$ & $\begin{array}{c}\text { HB-Line } \\
\text { Basis } \\
(\mathrm{g})\end{array}$ \\
\hline 1 & 0.63 & 15.2 & 578.4 & 70.3 & 228 \\
2 & 2.35 & 19.1 & 573.7 & 87.8 & 287 \\
3 & 4.32 & 20.4 & 568.3 & 92.6 & 305 \\
4 & 6.27 & 20.6 & 563.0 & 92.7 & 309 \\
\hline
\end{tabular}

To calculate the amount of Pu metal dissolved as a function of time, we followed the same procedure used in Experiments 1 and 2. The volume of solution at each sample time was estimated using the initial volume of solution, the volume of samples removed, and the measured volume $(560 \mathrm{~mL})$ following termination of the experiment. The volume of solution evaporated during the experiment was estimated at $15.5 \mathrm{~mL}$. We then used the measured $\mathrm{Pu}$ concentration and estimated volume to calculate the mass of $\mathrm{Pu}$ in solution (Appendix A). The calculated mass is expressed as a percentage of the total mass of $\mathrm{Pu}$ dissolved which includes the initial $\mathrm{Pu}$ metal $(11.59 \mathrm{~g})$, residual $\mathrm{Pu}$ metal $(0.84 \mathrm{~g})$, and the $\mathrm{PuO}_{2}$ solids $(0.07 \mathrm{~g})$. The mass of $\mathrm{Pu}$ dissolved as a function of time shows that $>92 \%$ of the total $\mathrm{Pu}$ dissolved during the $6.27 \mathrm{~h}$ dissolution cycle. Table 5 also provides an estimate of the mass of $\mathrm{Pu}$ which would dissolve in the HB-Line dissolvers using the solution volume to scale the mass of $\mathrm{Pu}$ dissolved during the experiment. The mass of Pu dissolved in $6.27 \mathrm{~h}(11.59 \mathrm{~g})$ scales to the dissolution of $309 \mathrm{~g}$ of $\mathrm{Pu}$ in the HB-Line dissolvers.

The data in Table 5 show that the rate of Pu metal dissolution in Experiment 3 slowed significantly beyond approximately $4 \mathrm{~h}$. This fact is also illustrated on Figure 3 . The $\mathrm{Pu}$ concentration appears to have reached a constant value. The slow rate of dissolution, at least in part, could be attributed to the diminishing surface area of the small bead of Pu remaining on the Ta surface. The reduction in the fluoride activity due to complexation with $\mathrm{Pu}$ also contributed to the reduction in the rate of dissolution. When fresh solution was used to dissolve the remaining metal, the dissolution proceeded at a significantly higher rate. Given time $(>4 \mathrm{~h})$, the $\mathrm{Pu}$ metal may have dissolved using the original solution or a significant portion of the metal may have oxidized to $\mathrm{PuO}_{2}$. If the metal oxidized to $\mathrm{PuO}_{2}$, we expect little of the material would have dissolved due to the fluoride complexation and the low $\mathrm{HNO}_{3}$ concentration. 


\section{Offgas Analyses}

The offgas analyses for each dissolution experiment are summarized in Table 6. The detection limit for $\mathrm{H}_{2}$ was $0.1 \mathrm{vol} \%$ (1000 ppmv) and the one sigma error associated with a measured value is $\pm 25 \%$.

Table 6 Gas Generation During Pu/Ta Dissolution Experiments

\begin{tabular}{cccccc}
\hline \hline Exp. & Sample & $\begin{array}{c}\text { Collection } \\
\text { Time } \\
(\mathrm{min})\end{array}$ & $\begin{array}{c}\text { Temp. } \\
\text { Range } \\
\left({ }^{\circ} \mathrm{C}\right)\end{array}$ & $\begin{array}{c}\text { Gas } \\
\text { Volume } \\
(\mathrm{mL})\end{array}$ & $\begin{array}{c}\mathrm{H}_{2} \\
\text { Conc. } \\
(\mathrm{vol} \%)\end{array}$ \\
\hline 1 & $11^{(1)}$ & 125 & $25-95$ & 72 & $<0.1$ \\
1 & 2 & 120 & $82-102$ & 68 & $<0.1$ \\
1 & 3 & 120 & $81-99$ & 10 & 0.1 \\
2 & 1 & 118 & $25-101$ & 260 & $<0.1$ \\
2 & 2 & 115 & $98-100$ & 30 & $<0.1$ \\
2 & 3 & 110 & 98 & 80 & $<0.1$ \\
3 & 1 & 37 & $25-99$ & 837 & $<0.1$ \\
3 & 2 & 103 & $93-99$ & 83 & $<0.1$ \\
3 & 3 & 122 & $91-98$ & 0 & $<0.1$ \\
3 & 4 & 105 & $94-101$ & 111 & $<0.1$ \\
\hline
\end{tabular}

(1) Slight gas leak observed in apparatus during sampling period.

(2) Dissolver cap opened briefly just prior to sampling.

Table 6 shows that the measured $\mathrm{H}_{2}$ concentration in the offgas samples was at or below the detection limit during the three dissolutions. In only one sample (collected during Experiment 1) was a measurable concentration detected. This concentration must be adjusted to account for dilution from gas in the free board region of the dissolving vessel, condenser, plastic tubing, and sample bulb. The calculations (Appendix B) assumed ideal mixing of the gases in the dissolving system and that variations in the gas temperature are negligible. For all of the gas samples, the dissolving vessel was opened to obtain solution samples prior to beginning a gas collection period; therefore, we assumed that no $\mathrm{H}_{2}$ remained in the system from the previous collection period. The adjusted $\mathrm{H}_{2}$ concentration for the third sample collected during Experiment 1 was $2.4 \mathrm{vol} \%$. The $\mathrm{H}_{2}$ generation rate for this period of the experiment was also calculated using the adjusted concentration, the gas volume, and the time required to collect the gas (Appendix B). The generation rate was $0.082 \mu$ mole $\mathrm{H}_{2} / \mathrm{min}$.

Table 6 also shows that the highest rates of gas generation occurred in the initial phases of the dissolutions. Throughout most of the dissolution process, brown gas was observed in the headspace of the dissolver flask, sample bulbs, and in the Tedlar ${ }^{\mathrm{TM}}$ bags. The brown color is indicative of $\mathrm{NO}_{2}$, which is not detectable by the $\mathrm{GC}$ used for these analyses. Although not shown in the table, the oxygen $\left(\mathrm{O}_{2}\right)$ content in all of samples was below the $21 \mathrm{vol} \%$ present in air. Sample bulbs were purged with nitrogen, which would slightly reduce the $\mathrm{O}_{2}$ content. The reduced $\mathrm{O}_{2}$ levels may also be due to the reaction of nitric oxide (NO) with $\mathrm{O}_{2}$ to form $\mathrm{NO}_{2}$. 
The presence of $\mathrm{H}_{2}$ in the offgas from a Pu metal dissolution is expected. Dissolution of metal proceeds by acid (equation 1) as well as nitrate oxidation (equations 2-4).

$$
\begin{gathered}
\mathrm{Pu}+4 \mathrm{HNO}_{3} \rightarrow \mathrm{Pu}\left(\mathrm{NO}_{3}\right)_{4}+2 \mathrm{H}_{2} \\
\mathrm{Pu}+8 \mathrm{HNO}_{3} \rightarrow \mathrm{Pu}\left(\mathrm{NO}_{3}\right)_{4}+4 \mathrm{NO}_{2}+4 \mathrm{H}_{2} \mathrm{O} \\
3 \mathrm{Pu}+16 \mathrm{HNO}_{3} \rightarrow 3 \mathrm{Pu}\left(\mathrm{NO}_{3}\right)_{4}+4 \mathrm{NO}+8 \mathrm{H}_{2} \mathrm{O} \\
2 \mathrm{Pu}+10 \mathrm{HNO}_{3} \rightarrow 2 \mathrm{Pu}\left(\mathrm{NO}_{3}\right)_{4}+\mathrm{N}_{2} \mathrm{O}+5 \mathrm{H}_{2} \mathrm{O}
\end{gathered}
$$

The dissolution of $\mathrm{Pu}$ metal by acid oxidation is maximized at low dissolution temperatures. The presence of $\mathrm{NO}_{2}$ gas, an indication of nitrate oxidation, was not observed below approximately $70{ }^{\circ} \mathrm{C}$.

Small amounts of $\mathrm{H}_{2}$, consistent with the value measured during Experiment 1, have been observed during the dissolution of $\mathrm{Pu}$ metal in $\mathrm{HNO}_{3}$ /fluoride systems. Rudisill et al. [3] measured $\mathrm{a} \mathrm{H}_{2}$ concentration of $2.6 \mathrm{vol} \%$ in a gas sample collected during the dissolution of $\mathrm{Pu}$ metal using a $4 \mathrm{M} \mathrm{HNO}_{3}$ solution containing $0.1 \mathrm{M} \mathrm{KF}$. However, prior to adjusting the concentration for dilution by the gas originally in the dissolving system used in that study, the measured concentration was only 0.47 vol \%. Miner et al.[8] reported that gas samples withdrawn from just above the surface of nitric/hydrofluoric acid solutions used to dissolve alpha phase $\mathrm{Pu}$ metal always contained $\leq 0.3$ vol $\% \mathrm{H}_{2}$. Therefore, small concentrations of $\mathrm{H}_{2}$ produced during the $\mathrm{Pu} / \mathrm{Ta}$ dissolution experiments could have easily been diluted below the detection limit of the GC.

The total volumes of gas generated during Experiments 1-3 were $0.31,0.83,0.87 \mathrm{~mole} / \mathrm{mole}$ of $\mathrm{Pu}$ metal dissolved (or oxidized), respectively. The lower gas generation measured in Experiment 1 can be attributed, at least in part, to the leak which occurred in the dissolving system during the early part of the dissolution when the majority of the offgas was generated.

\section{$\underline{\text { Trace Metal Analyses }}$}

The concentrations of selected trace metals in the dissolver solution were measured by ICP-ES, AAS, and CVAAS. The measured concentrations and one sigma percent uncertainties are summarized in Table 7 for each dissolution experiment. Unless noted in the table, the analyses were performed by ICP-ES. The high concentration of K reported in Table 7 is due to the use of $\mathrm{KF}$ in the dissolving solution. The reported $\mathrm{K}$ concentrations are equivalent to $\mathrm{KF}$ concentrations of $0.141 \mathrm{M}, 0.104 \mathrm{M}$, and $0.104 \mathrm{M}$, for Experiments 1-3, respectively. The concentrations measured for Experiments 2 and 3 appear biased low compared to the value measured for Experiment 1 and the prepared concentrations $(0.175 \mathrm{M})$. We attribute these inconsistent results to interferences associated with the high levels of $\mathrm{Pu}$ in the solutions. The analysis of $\mathrm{K}$ by AAS would have provided more accurate values. The high concentrations of cerium are also probably biased high due to interferences associated with the high concentrations of $\mathrm{Pu}$ in the solutions. Elevated concentrations of sodium, boron, and silicon are likely due to the 
corrosion of the Pyrex ${ }^{\circledR}$ dissolvers used in the dissolution. The ${ }^{235} \mathrm{U}$ observed in the solutions is produced by the alpha decay of ${ }^{239} \mathrm{Pu}$.

Table 7 Trace Metal Analyses for Pu/Ta Composite Dissolutions

\begin{tabular}{|c|c|c|c|c|c|c|}
\hline \multirow[t]{2}{*}{ Element } & \multicolumn{2}{|c|}{ Experiment 1} & \multicolumn{2}{|c|}{ Experiment 2} & \multicolumn{2}{|c|}{ Experiment 3} \\
\hline & $\begin{array}{l}\text { Conc. } \\
(\mathrm{mg} / \mathrm{L})\end{array}$ & $\begin{array}{c}\text { Uncertain. } \\
(\%)\end{array}$ & $\begin{array}{l}\text { Conc. } \\
(\mathrm{mg} / \mathrm{L})\end{array}$ & $\begin{array}{c}\text { Uncertain. } \\
(\%)\end{array}$ & $\begin{array}{l}\text { Conc. } \\
(\mathrm{mg} / \mathrm{L})\end{array}$ & $\begin{array}{c}\text { Uncertain. } \\
(\%)\end{array}$ \\
\hline$\overline{\mathrm{Ag}}$ & 10.1 & 10 & 7.41 & 10 & 8.00 & 10 \\
\hline $\mathrm{Al}$ & 11.5 & 10 & 11.5 & 10 & 12.8 & 10 \\
\hline $\mathrm{As}^{(1)}$ & $<0.0275$ & NA & $<0.0275$ & NA & $<0.0275$ & NA \\
\hline B & 31.6 & 11 & 26.8 & 12 & 30.4 & 11 \\
\hline $\mathrm{Ba}$ & 9.45 & 10 & 9.48 & 11 & 10.0 & 10 \\
\hline $\mathrm{Be}$ & 0.456 & 10 & $<0.823$ & NA & $<0.823$ & NA \\
\hline $\mathrm{Ca}$ & $<1.88$ & NA & $<2.26$ & NA & $<2.26$ & NA \\
\hline $\mathrm{Cd}$ & $<0.634$ & NA & $<0.765$ & NA & $<0.765$ & NA \\
\hline $\mathrm{Ce}$ & 209 & 10 & 140 & 10 & 151 & 10 \\
\hline $\mathrm{Cr}$ & $<2.85$ & NA & $<3.93$ & NA & $<3.93$ & NA \\
\hline $\mathrm{Cu}$ & 55.2 & 10 & 33.8 & 10 & 36.9 & 10 \\
\hline $\mathrm{Fe}$ & $<0.834$ & NA & 1.56 & 15 & 2.65 & 24 \\
\hline $\mathrm{Gd}$ & 10.6 & 10 & 9.76 & 10 & 10.7 & 10 \\
\hline $\mathrm{Hg}^{(2)}$ & $<0.11$ & NA & $<0.11$ & NA & $<0.11$ & NA \\
\hline $\mathrm{K}$ & 5510 & 10 & 4070 & 10 & 4070 & 10 \\
\hline $\mathrm{La}$ & 17.7 & 10 & 16.8 & 10 & 17.6 & 10 \\
\hline $\mathrm{Li}$ & $<4.00$ & NA & $<6.86$ & NA & $<6.86$ & NA \\
\hline $\mathrm{Mg}$ & $<4.91$ & NA & 1.37 & 10 & 1.69 & 10 \\
\hline $\mathrm{Mn}$ & 12 & 10 & 10.2 & 10 & 11.2 & 10 \\
\hline Mo & 48.3 & 12 & 44.6 & 46 & 43.1 & 13 \\
\hline $\mathrm{Na}$ & 62.8 & 10 & 19.2 & 15 & 19.6 & 10 \\
\hline $\mathrm{Ni}$ & $<4.75$ & NA & $<5.69$ & NA & $<5.69$ & NA \\
\hline $\mathrm{P}$ & $<31.9$ & NA & $<37.3$ & NA & $<37.3$ & NA \\
\hline $\mathrm{Pb}$ & $<50.2$ & NA & $<48.7$ & NA & $<48.7$ & NA \\
\hline S & $<9.91$ & NA & $<12.7$ & NA & $<12.7$ & NA \\
\hline $\mathrm{Sb}$ & 39 & 25 & 27.8 & 14 & 27.0 & 11 \\
\hline $\mathrm{Se}^{(1)}$ & $<0.0550$ & NA & $<0.0550$ & NA & $<0.0550$ & NA \\
\hline $\mathrm{Si}$ & 109 & 10 & 120 & 10 & 95.5 & 10 \\
\hline $\mathrm{Sn}$ & 88.3 & 16 & $<110$ & NA & $<110$ & NA \\
\hline $\mathrm{Sr}$ & $<3.19$ & NA & $<7.01$ & NA & $<7.01$ & NA \\
\hline $\mathrm{Ti}$ & $<0.111$ & NA & $<0.381$ & NA & $<0.381$ & NA \\
\hline $\mathrm{U}$ & 505 & 10 & 287 & 10 & 315 & 10 \\
\hline V & $<42.8$ & NA & 3.42 & 30 & 4.65 & 11 \\
\hline $\mathrm{Zn}$ & $<5.16$ & NA & $<2.97$ & NA & $<2.97$ & NA \\
\hline $\mathrm{Zr}$ & $<0.314$ & NA & $<0.789$ & NA & $<0.789$ & NA \\
\hline
\end{tabular}

(1) Measured by AAS.

(2) Measured by CVAAS.

NA - Not Applicable 


\section{$\underline{\text { Acid Analyses }}$}

The free and total acid concentrations in the final dissolving solutions for Experiments 1-3 are shown in Table 8. The one sigma uncertainty in the acid concentrations is $\pm 10 \%$.

Table 8 Acid Analyses for $\mathrm{Pu} / \mathrm{Ta}$ Dissolution Experiments

\begin{tabular}{ccc}
\hline \hline Experiment & $\begin{array}{c}\text { Free Acid } \\
(\mathrm{M})\end{array}$ & $\begin{array}{c}\text { Total Acid } \\
(\mathrm{M})\end{array}$ \\
\hline 1 & 3.15 & 3.79 \\
2 & 3.15 & 4.14 \\
3 & 3.73 & 3.96 \\
\hline
\end{tabular}




\section{Conclusions}

Three experiments were performed to optimize the HB-Line flowsheet currently used for the dissolution of composite materials containing $\mathrm{Pu}$ and Ta metal. The three dissolutions were performed using a $4 \mathrm{M} \mathrm{HNO}_{3}$ solution containing either 0.15 or $0.175 \mathrm{M} \mathrm{KF}$ at $90-100{ }^{\circ} \mathrm{C}$. When $0.15 \mathrm{M} \mathrm{KF}$ was used in the dissolving solution, 95.5\% of the Pu metal dissolved in approximately $6 \mathrm{~h}$. The mass of $\mathrm{Pu}$ dissolved is equivalent to the dissolution of $343 \mathrm{~g}$ of $\mathrm{Pu}$ in the HB-Line dissolvers. We speculate that the small amount of remaining Pu metal would have dissolved if the dissolution time had been extended. This assumption is based on the steady increase in the $\mathrm{Pu}$ concentration observed during the last several hours of the dissolution experiment. A small amount of $\mathrm{Pu}$ metal was also converted to $\mathrm{PuO}_{2}$ during the dissolution. We attributed its formation to the complexation of fluoride by the dissolved $\mathrm{Pu}$. The fluoride became unavailable to catalyze the dissolution of $\mathrm{PuO}_{2}$ which formed on the surface of the metal. Incomplete dissolution of the $\mathrm{PuO}_{2}$ is not a solubility limitation. The complexation of fluoride and low acidity slow the dissolution of $\mathrm{PuO}_{2}$ which effectively inhibits its dissolution.

Two experiments were performed using a dissolving solution containing $0.175 \mathrm{M} \mathrm{KF}$. In the first experiment, we achieved complete dissolution of the $\mathrm{Pu}$ metal in $6 \mathrm{~h}$. No $\mathrm{PuO}_{2}$ solids were produced. The mass of Pu solubilized scales to the dissolution of $358 \mathrm{~g}$ of $\mathrm{Pu}$ in the HB-Line dissolvers. The second experiment using $0.175 \mathrm{M} \mathrm{KF}$ was prematurely terminated after approximately $6 \mathrm{~h}$ following the dissolution of $92.7 \%$ of the $\mathrm{Pu}$; however, dissolution of additional $\mathrm{Pu}$ was severely limited due to the slow dissolution rate observed beyond approximately $4 \mathrm{~h}$. We also observed a small amount of $\mathrm{PuO}_{2}$ solids in the dissolving solution. The slow rate of dissolution, at least in part, could be attributed to the diminishing surface area of the remaining $\mathrm{Pu}$. The reduction in the fluoride activity due to complexation with $\mathrm{Pu}$ also contributed to the reduction in the rate of dissolution based on the significantly higher rate of dissolution observed when the remaining metal was dissolved using fresh solution. Given time ( $>4 \mathrm{~h}$ ), the Pu metal may have dissolved using the original solution or a significant portion of the metal may have oxidized to $\mathrm{PuO}_{2}$. If the metal oxidized to $\mathrm{PuO}_{2}$, we expect little of the material would have dissolved due to the fluoride complexation and the low $\mathrm{HNO}_{3}$ concentration. The mass of $\mathrm{Pu}$ dissolved in the second experiment scales to the dissolution of $309 \mathrm{~g}$ of $\mathrm{Pu}$ in the HB-Line dissolvers.

The $\mathrm{H}_{2}$ concentration in the offgas samples from the dissolutions was at or below the detection limit $(<0.1 \mathrm{vol} \%)$. A measurable concentration was only detected in one sample collected during Experiment 1. The concentration when adjusted for dilution by the air in the dissolution system was $2.4 \mathrm{vol} \%$. The detection of a concentration of this magnitude is consistent with values reported by Rudisill et al. [3] and Miner et al. [8] for the dissolution of Pu metal using solutions containing $\mathrm{HNO}_{3}$ and fluoride. The small concentrations of $\mathrm{H}_{2}$ produced during the $\mathrm{Pu} / \mathrm{Ta}$ dissolution experiments were likely diluted below the detection limit of the GC. 


\section{This page was intentionally left blank.}




\section{Flowsheet Recommendations}

Based on the data from the $\mathrm{Pu} / \mathrm{Ta}$ flowsheet optimization experiments, we recommend the use of a $4 \mathrm{M} \mathrm{HNO}_{3}$ solution containing $0.175 \mathrm{M} \mathrm{KF}$ for the dissolution of $300 \mathrm{~g}$ of $\mathrm{Pu}$ metal in the $15 \mathrm{~L}$ working volume of the HB-Line dissolver. A dissolution temperature of nominally $95^{\circ} \mathrm{C}$ should allow for essentially complete dissolution of the metal in $6 \mathrm{~h}$. Although the $\mathrm{H}_{2}$ concentration in the offgas was at or below the detection limit of the GC used in these experiments, small concentrations ( $<3$ vol \%) of $\mathrm{H}_{2}$ are produced in the offgas during $\mathrm{Pu}$ metal dissolutions. Therefore, appropriate controls must be established to address the small $\mathrm{H}_{2}$ generation rates in accordance with this work and the earlier flowsheet demonstrated for $\mathrm{Pu}$ metal. 


\section{This page was intentionally left blank.}




\section{References}

1. T. S. Rudisill, M. L. Crowder, and M. G. Bronikowski, Dissolution of Fissile Materials Containing Vanadium and Tantalum Metals, WSRC-TR-2006-00159, Washington Savannah River Company, Aiken, SC (May 2006).

2. M. G Bronikowski, T. S. Rudisill, and M. L. Crowder, Task Technical and Quality Assurance Plan - Dissolution of Plutonium and Tantalum Metals in HB-Line, Report WSRC-TR-2007-00131, Washington Savannah River Company, Aiken, SC (January 2007).

3. T. S. Rudisill and M. L. Crowder, Dissolution of FB-Line Residues Containing Beryllium Metal, Report WSRC-TR-2005-00042, Revision 1, Washington Savannah River Company, Aiken, SC (October 2005).

4. M. G. Bronikowski, J. H. Scogin, and R. A. Pierce, Vanadium and Tantalum Disposition for HB-Line, Report WSRC-TR-2005-00134, Westinghouse Savannah River Company, Aiken, SC (March 2005).

5. J.E. Laurinat, M. L. Crowder, and Glen F Kessinger, Information on the Solubility of Plutonium in Nitric Acid/Fluoride Solutions, Report SRNL-ATS-2005-00031, Rev.1, Washington Savannah River Company, Aiken, SC (May 2005).

6. G. A. Burney, Dissolution of Rocky Flats Foundry $\mathrm{PuO}_{2}$, Report DPST-84-782, E. I. du Pont de Nemours \& Co., Aiken, SC (October 1984).

7. G. F. Molen, Dissolution of Plutonium Oxide, Report RFP-922, The Dow Chemical Company, Golden, CO (1967).

8. F. J. Miner, J. H. Nairn, and J. W. Berry, Dissolution of Plutonium in Dilute Nitric Acid, I\&EC Product Research and Development, 9, pp. 402-405 (1969). 


\section{This page was intentionally left blank.}


WSRC-STI-2007-00285

Revision 0

Figure 1 Dissolution Vessel

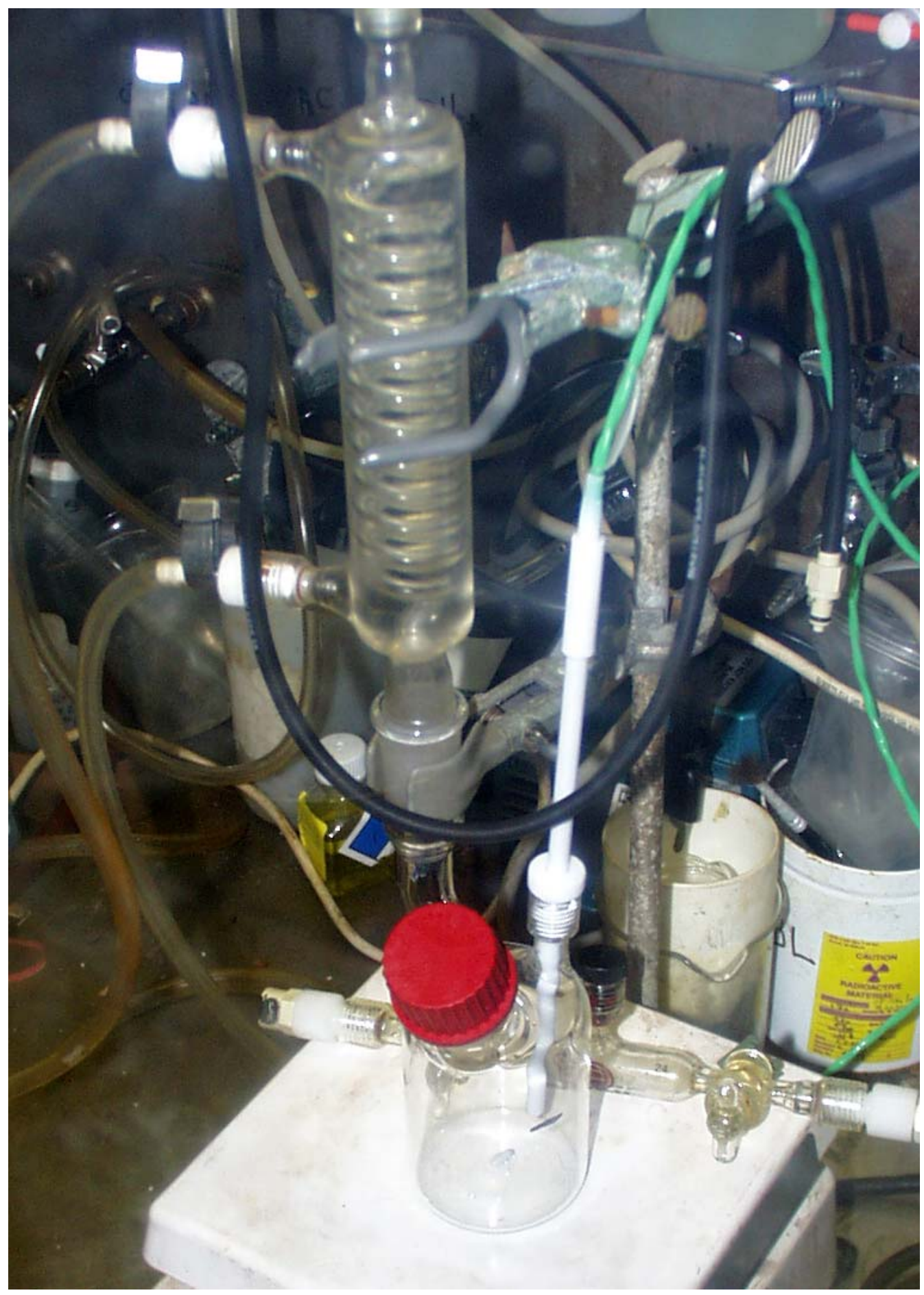




\section{This page was intentionally left blank.}


Figure 2 Three-neck Flask Dissolving System and Glass Basket

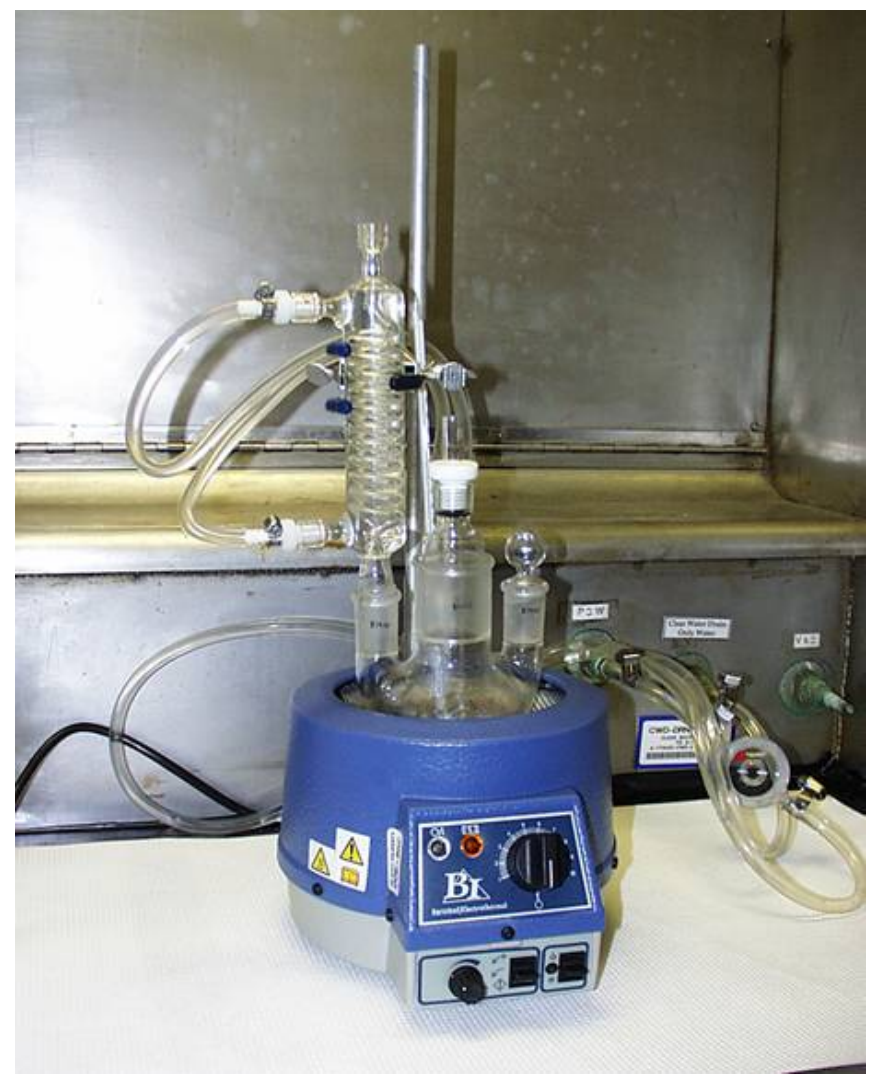

Heating Mantle and Dissolution Vessel

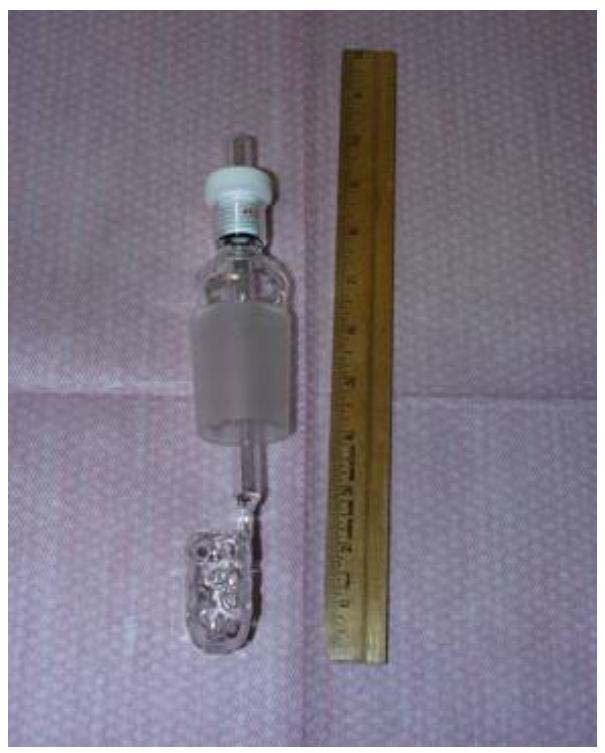

Glass Dissolving Basket 


\section{This page was intentionally left blank.}


Figure 3 Dissolution of Composite Materials Containing Pu and Ta Metals

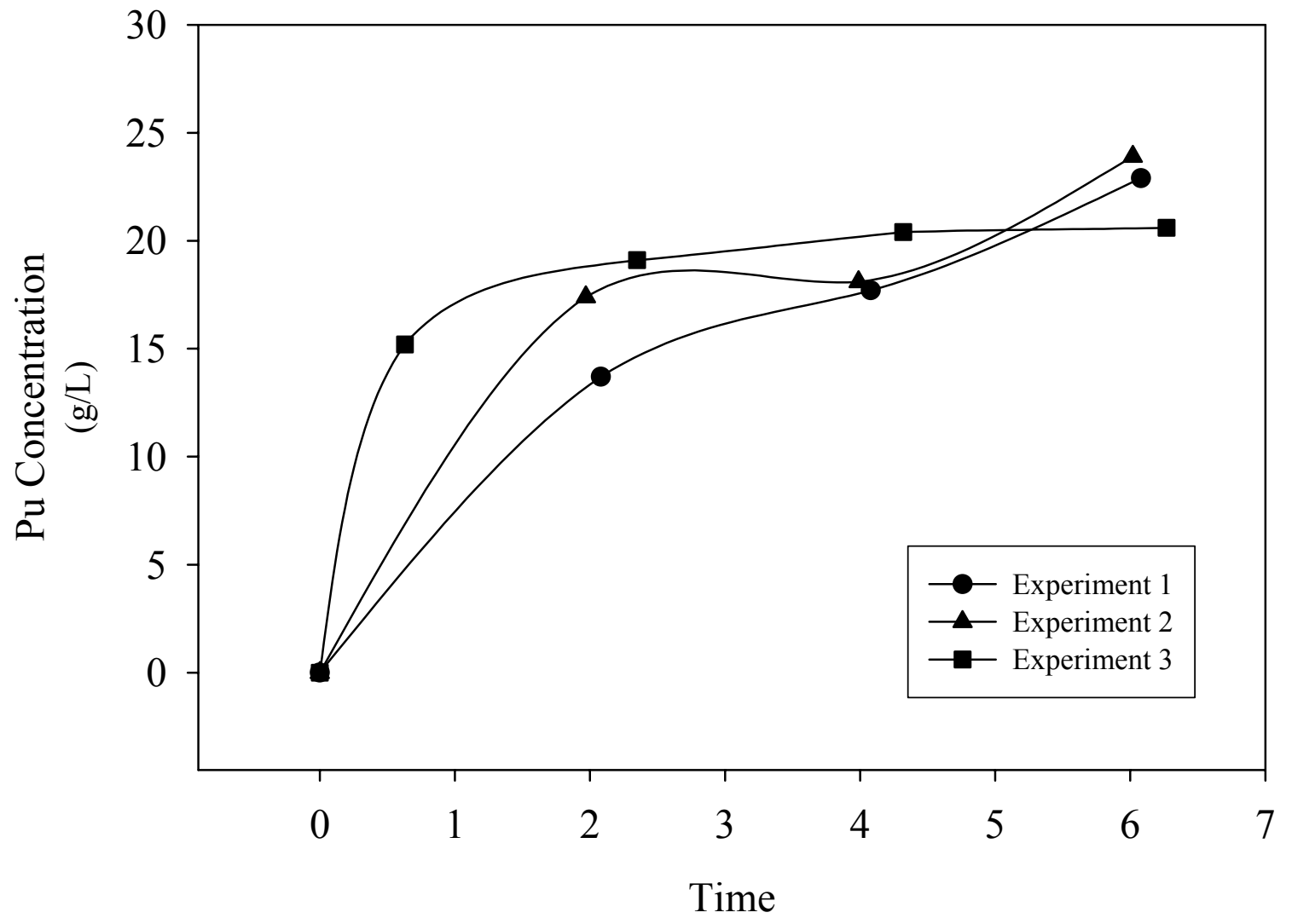

(h) 


\section{This page was intentionally left blank.}


WSRC-STI-2007-00285

Revision 0

\section{Appendix A Plutonium Analyses for Pu/Ta Composite Material Dissolutions}

\section{Experiment 1}

The ${ }^{239} \mathrm{Pu}$ gamma activities in the samples from Experiment 1 are given in Table A.1.

Table A.1 Summary of Pu Analyses for Experiment 1

\begin{tabular}{lccccc}
\hline \hline $\begin{array}{c}\text { Sample } \\
\text { Description }\end{array}$ & ${ }^{239} \mathrm{Pu}$ & $\begin{array}{c}\mathrm{Pu} \\
\mathrm{Conc} . \\
(\mathrm{g} / \mathrm{L})\end{array}$ & $\begin{array}{c}\text { Solution } \\
\text { Volume } \\
(\mathrm{mL})\end{array}$ & $\begin{array}{c}\mathrm{Pu} \\
\text { Dissolved } \\
(\mathrm{g})\end{array}$ & $\begin{array}{c}\mathrm{Pu} \\
\text { Dissolved } \\
(\%)\end{array}$ \\
\hline 2.08 h Sample & $1.78 \mathrm{E}+09$ & 13.7 & 210.0 & 2.88 & 57.5 \\
4.08 h Sample & $2.29 \mathrm{E}+09$ & 17.7 & 209.5 & 3.70 & 73.8 \\
6.08 h Sample & $2.97 \mathrm{E}+09$ & 22.9 & 209.0 & 4.79 & 95.5 \\
$\mathrm{Remaining} \mathrm{Metal}$ & $3.65 \mathrm{E}+08$ & 2.8 & 54.0 & 0.15 & 3.0 \\
$\mathrm{PuO}_{2}$ Solids & $1.64 \mathrm{E}+08$ & 1.3 & 57.0 & 0.07 & 1.4 \\
\hline
\end{tabular}

To convert the gamma activities to concentration values, a specific activity of $1.38 \times 10^{11} \mathrm{dpm} / \mathrm{g}$ was used for ${ }^{239} \mathrm{Pu}$. The total $\mathrm{Pu}$ concentration was then calculated based on $94 \mathrm{wt} \%{ }^{239} \mathrm{Pu}$ in weapons grade $\mathrm{Pu}$.

The solution volume in Table A.1 was calculated by initially estimating the rate that solution was lost by evaporation from the dissolver. The evaporation rate was estimated using the initial volume of solution $\left(\mathrm{V}_{\text {initial }}\right)$, the number $\left(\mathrm{N}_{\text {sample }}\right)$ and volume $\left(\mathrm{V}_{\text {sample }}\right)$ of the samples removed, and the measured volume $\left(\mathrm{V}_{\text {final }}\right)$ following $6.08 \mathrm{~h}(\mathrm{t})$ of cumulative heating (equation $\left.\mathrm{A} .1\right)$. The calculation assumed uniform evaporative losses during heating.

Evap. Rate $=\frac{\mathrm{V}_{\text {initial }}-\mathrm{N}_{\text {sample }} \mathrm{V}_{\text {sample }}-\mathrm{V}_{\text {final }}}{\mathrm{t}}$

The evaporation rate for Experiment 1 is calculated below (equation A.2). For this experiment, the final volume was measured following the removal of 3 samples for Pu analyses, 4 samples for trace metal analyses, and 1 sample for free and total acid analyses.

Evap. Rate $=\frac{210.0 \mathrm{~mL}-(8 \text { samples })\left(\frac{0.5 \mathrm{~mL}}{\text { sample }}\right)-206.0 \mathrm{~mL}}{6.1 \mathrm{~h}}=0.0 \frac{\mathrm{mL}}{\mathrm{h}}$

Using an evaporation rate of zero, the solution volume at each sample time during the $\mathrm{Pu}$ metal dissolution is calculated in Table A.2. 
Table A.2 Estimated Solution Volume During Experiment 1

\begin{tabular}{cccccc}
\hline \hline $\begin{array}{c}\text { Sample } \\
\text { No. }\end{array}$ & $\begin{array}{c}\text { Cumulative } \\
\text { Time } \\
(\mathrm{h})\end{array}$ & $\begin{array}{c}\text { Evaporation } \\
\text { Loss } \\
(\mathrm{mL})\end{array}$ & $\begin{array}{c}\text { Samples } \\
\text { Removed }\end{array}$ & $\begin{array}{c}\text { Sample } \\
\text { Volume } \\
(\mathrm{mL})\end{array}$ & $\begin{array}{c}\text { Estimated } \\
\text { Volume } \\
(\mathrm{mL})\end{array}$ \\
\hline 0 & 0 & 0 & 0 & 0 & 210.0 \\
1 & 2.08 & 0 & 1 & 0.5 & 210.0 \\
2 & 4.08 & 0 & 1 & 0.5 & 209.5 \\
3 & 6.08 & 0 & 0 & 0 & 209.0 \\
\hline
\end{tabular}

The mass of $\mathrm{Pu}$ dissolved at each sample time and the mass of $\mathrm{Pu}$ in the remaining metal and $\mathrm{PuO}_{2}$ solids were calculated from the concentration and volume of each sample (Table A.1). The total amount of $\mathrm{Pu}$ dissolved during Experiment $1(5.01 \mathrm{~g})$ was calculated as the sum of the mass of material dissolved during the three dissolutions. The mass of $\mathrm{Pu}$ dissolved at each sample time and in the subsequent dissolutions was then calculated as a percentage of the total Pu mass using this value (Table A.1).

\section{Experiment 2}

The ${ }^{239} \mathrm{Pu}$ gamma activities in the samples from Experiment 2 are given in Table A.3.

Table A.3 Summary of Pu Analyses for Experiment 2

\begin{tabular}{cccccc}
\hline \hline $\begin{array}{c}\text { Sample } \\
\text { Description }\end{array}$ & ${ }^{239} \mathrm{Pu}$ & $\begin{array}{c}\mathrm{Pu} \\
\text { Conc. } \\
(\mathrm{g} / \mathrm{L})\end{array}$ & $\begin{array}{c}\text { Solution } \\
\text { Volume } \\
(\mathrm{mL})\end{array}$ & $\begin{array}{c}\mathrm{Pu} \\
\text { Dissolved } \\
(\mathrm{g})\end{array}$ & $\begin{array}{c}\mathrm{Pu} \\
\text { Dissolved } \\
(\%)\end{array}$ \\
\hline 1.97 h Sample & $2.26 \mathrm{E}+09$ & 17.4 & 190.7 & 3.32 & 76.0 \\
3.99 h Sample & $2.34 \mathrm{E}+09$ & 18.0 & 186.9 & 3.37 & 77.1 \\
6.02 h Sample & $3.10 \mathrm{E}+09$ & 23.9 & 183.0 & 4.37 & 100.0 \\
\hline
\end{tabular}

To convert the gamma activities to concentration values, a specific activity of $1.38 \times 10^{11} \mathrm{dpm} / \mathrm{g}$ was used for ${ }^{239} \mathrm{Pu}$. The total $\mathrm{Pu}$ concentration was then calculated based on $94 \mathrm{wt} \%{ }^{239} \mathrm{Pu}$ in weapons grade $\mathrm{Pu}$.

The solution volume in Table A.3 was calculated following the same procedure as used in Experiment 1 . The evaporation rate was initially calculated using equation A.1. The calculation assumed uniform evaporative losses during heating (equation A.3). For this experiment, the final volume was measured following the removal of 3 samples for $\mathrm{Pu}$ analyses, 4 samples for trace metal analyses, and 1 sample for free and total acid analyses.

Evap. Rate $=\frac{194.0 \mathrm{~mL}-(8 \text { samples })\left(\frac{0.5 \mathrm{~mL}}{\text { sample }}\right)-180.0 \mathrm{~mL}}{6.02 \mathrm{~h}}=1.66 \frac{\mathrm{mL}}{\mathrm{h}}$ 
Using an evaporation rate of $1.66 \mathrm{~mL} / \mathrm{h}$, the solution volume at each sample time during the $\mathrm{Pu}$ metal dissolution is calculated in Table A.4.

Table A.4 Estimated Solution Volume During Experiment 2

\begin{tabular}{cccccc}
\hline \hline $\begin{array}{c}\text { Sample } \\
\text { No. }\end{array}$ & $\begin{array}{c}\text { Cumulative } \\
\text { Time } \\
(\mathrm{h})\end{array}$ & $\begin{array}{c}\text { Evaporation } \\
\text { Loss } \\
(\mathrm{mL})\end{array}$ & $\begin{array}{c}\text { Samples } \\
\text { Removed }\end{array}$ & $\begin{array}{c}\text { Sample } \\
\text { Volume } \\
(\mathrm{mL})\end{array}$ & $\begin{array}{c}\text { Estimated } \\
\text { Volume } \\
(\mathrm{mL})\end{array}$ \\
\hline 0 & 0 & 0 & 0 & 0 & 194.0 \\
1 & 1.97 & 3.3 & 1 & 0.5 & 190.7 \\
2 & 3.99 & 3.4 & 1 & 0.5 & 186.9 \\
3 & 6.02 & 3.4 & 0 & 0 & 183.0 \\
\hline
\end{tabular}

The mass of $\mathrm{Pu}$ dissolved at each sample time was calculated from the concentration and volume of each sample (Table A.3). This value was then expressed as a percentage of the total Pu mass dissolved using the mass of material solubilized after $6.02 \mathrm{~h}$.

\section{Experiment 3}

The ${ }^{239} \mathrm{Pu}$ gamma activities in the samples from Experiment 3 are given in Table A.5.

Table A.5 Summary of Pu Analyses for Experiment 3

\begin{tabular}{lccccc}
\hline \hline $\begin{array}{c}\text { Sample } \\
\text { Description }\end{array}$ & ${ }^{239} \mathrm{Pu}$ & $\begin{array}{c}\mathrm{Pu} \\
\mathrm{Conc} \\
(\mathrm{g} / \mathrm{L})\end{array}$ & $\begin{array}{c}\text { Solution } \\
\text { Volume } \\
(\mathrm{mL})\end{array}$ & $\begin{array}{c}\mathrm{Pu} \\
\text { Dissolved } \\
(\mathrm{g})\end{array}$ & $\begin{array}{c}\mathrm{Pu} \\
\text { Dissolved } \\
(\%)\end{array}$ \\
\hline 0.63 h Sample & $1.97 \mathrm{E}+09$ & 15.2 & 578.4 & 8.78 & 70.3 \\
2.35 h Sample & $2.48 \mathrm{E}+09$ & 19.1 & 573.7 & 10.97 & 87.8 \\
4.32 h Sample & $2.64 \mathrm{E}+09$ & 20.4 & 568.3 & 11.57 & 92.6 \\
6.27 h Sample & $2.67 \mathrm{E}+09$ & 20.6 & 563.0 & 11.59 & 92.7 \\
$\mathrm{Remaining} \mathrm{Metal}_{\mathrm{PuO}}$ Solids & $9.35 \mathrm{E}+08$ & 7.2 & 117.0 & 0.84 & 6.8 \\
\hline
\end{tabular}

To convert the gamma activities to concentration values, a specific activity of $1.38 \times 10^{11} \mathrm{dpm} / \mathrm{g}$ was used for ${ }^{239} \mathrm{Pu}$. The total $\mathrm{Pu}$ concentration was then calculated based on $94 \mathrm{wt} \%{ }^{239} \mathrm{Pu}$ in weapons grade $\mathrm{Pu}$.

The solution volume in Table A.5 was calculated following the same procedure used in Experiments 1 and 2. The evaporation rate was initially calculated using equation A.1. The calculation assumed uniform evaporative losses during heating (equation A.4). For this experiment, the final volume was measured following the removal of 4 samples for Pu analyses, 4 samples for trace metal analyses, and 1 sample for free and total acid analyses. 
Evap. Rate $=\frac{580.0 \mathrm{~mL}-(9 \text { samples })\left(\frac{0.5 \mathrm{~mL}}{\text { sample }}\right)-560.0 \mathrm{~mL}}{6.27 \mathrm{~h}}=2.47 \frac{\mathrm{mL}}{\mathrm{h}}$

Using an evaporation rate of $2.47 \mathrm{~mL} / \mathrm{h}$, the solution volume at each sample time during the $\mathrm{Pu}$ metal dissolution is calculated in Table A.6.

Table A.6 Estimated Solution Volume During Experiment 3

\begin{tabular}{cccccc}
\hline \hline $\begin{array}{c}\text { Sample } \\
\text { No. }\end{array}$ & $\begin{array}{c}\text { Cumulative } \\
\text { Time } \\
(\mathrm{h})\end{array}$ & $\begin{array}{c}\text { Evaporation } \\
\text { Loss } \\
(\mathrm{mL})\end{array}$ & $\begin{array}{c}\text { Samples } \\
\text { Removed }\end{array}$ & $\begin{array}{c}\text { Sample } \\
\text { Volume } \\
(\mathrm{mL})\end{array}$ & $\begin{array}{c}\text { Estimated } \\
\text { Volume } \\
(\mathrm{mL})\end{array}$ \\
\hline 0 & 0 & 0 & 0 & 0 & 580.0 \\
1 & 0.63 & 1.8 & 1 & 0.5 & 578.4 \\
2 & 2.35 & 4.9 & 1 & 0.5 & 573.7 \\
3 & 4.32 & 5.7 & 1 & 0.5 & 568.3 \\
4 & 6.27 & 5.6 & 1 & 0.5 & 563.0 \\
\hline
\end{tabular}

The mass of $\mathrm{Pu}$ dissolved at each sample time and the mass of $\mathrm{Pu}$ in the remaining metal and $\mathrm{PuO}_{2}$ solids were calculated from the concentration and volume of each sample (Table A.5). The total amount of $\mathrm{Pu}$ dissolved during Experiment 3 (12.50 g) was calculated as the sum of the mass of material dissolved during the three dissolutions. The mass of $\mathrm{Pu}$ dissolved at each sample time and in the subsequent dissolutions was then calculated as a percentage of the total $\mathrm{Pu}$ mass using this value (Table A.5). 
WSRC-STI-2007-00285

Revision 0

\section{Appendix B Calculation of Adjusted $\mathrm{H}_{2}$ Concentration and Gas Generation Rates}

\section{$\underline{\text { Adjusted } \mathrm{H}_{2}} \underline{\text { Concentration }}$}

The $\mathrm{H}_{2}$ concentration measured in the third gas sample during Experiment 1 must be corrected to account for dilution from gas in the dissolving vessel, condenser, plastic tubing, and sample bulb. To calculate the adjusted concentration, ideal mixing of the gases in the void space is assumed and the effect of temperature variations in the gas is assumed negligible. For all of the gas samples, the dissolving vessel was opened to obtain solution samples prior to beginning a gas collection period; therefore it was assumed that no $\mathrm{H}_{2}$ remained in the system from the previous collection period. The adjusted $\mathrm{H}_{2}$ concentration is calculated by material balance,

$$
\mathrm{C}_{\text {gen }} \mathrm{V}_{\text {gen }}=\mathrm{C}_{\text {measured }}\left(\mathrm{V}_{\text {void }}+\mathrm{V}_{\text {bulb }}+\mathrm{V}_{\text {gen }}\right)-\mathrm{C}_{\text {initial }} \mathrm{V}_{\text {void }}
$$

where: $\mathrm{C}_{\text {gen }}=$ concentration of $\mathrm{H}_{2}$ in the generated gas ( vol \%)

$\mathrm{C}_{\text {measured }}=$ concentration of $\mathrm{H}_{2}$ measured in a gas sample $(\mathrm{vol} \%)$

$\mathrm{C}_{\text {initial }}=$ concentration of $\mathrm{H}_{2}$ before the sample collection ( $\mathrm{vol} \%$ )

$\mathrm{V}_{\text {gen }}=$ volume of gas collected in the Tedlar ${ }^{\circledR}$ bag $(\mathrm{mL})$

$\mathrm{V}_{\text {void }}=$ void volume of dissolving vessel, condenser, and plastic tubing $(\mathrm{mL})$

$\mathrm{V}_{\text {bulb }}=$ volume of the gas sample bulb $(\mathrm{mL})$.

The total capacity of the glass dissolving vessel used in Experiment 1 was $374 \mathrm{~mL}$. The capacity was measured by filling the vessel with water. The void volume of the condenser and plastic tubing used to connect the sample bulb and Tedlar ${ }^{\circledR}$ gas collection bag to the vessel were 34 and $6 \mathrm{~mL}$, respectively. The volume of the condenser was measured by filling with water and the volume of the tubing was calculated from the length and inside diameter. The void volume used to calculate the adjusted $\mathrm{H}_{2}$ concentration in the gas sample is summarized in Table B.1. The volume of the gas sample bulb was nominally $25 \mathrm{~mL}$.

Table B.1 Equipment Void Volumes for Experiment 1

\begin{tabular}{cc}
\hline \hline Description & $\begin{array}{c}\text { Volume } \\
(\mathrm{mL})\end{array}$ \\
\hline Dissolution Vessel & 374 \\
Condenser & 34 \\
Tubing & 6 \\
Solution & 210 \\
& \\
$\mathrm{~V}_{\text {void }}$ & 204 \\
$\mathrm{~V}_{\text {bulb }}$ & 25 \\
\hline
\end{tabular}

The measured $\mathrm{H}_{2}$ concentration in the gas sample was $0.1 \mathrm{vol} \%$. The volume of gas collected during the sample period was $10 \mathrm{~mL}$. Using the measured concentration, gas generation volume, and the void volumes given in Table B.1, the adjusted concentration is calculated below (equation B.2). 
$\mathrm{C}_{\text {gen }}=\frac{0.1 \mathrm{vol} \%(204 \mathrm{~mL}+25 \mathrm{~mL}+10 \mathrm{~mL})}{10 \mathrm{~mL}}=2.4 \mathrm{vol} \%$

\section{$\underline{\mathrm{H}}_{2}$ Generation Rate}

The $\mathrm{H}_{2}$ generation rate was calculated from the adjusted concentration, the gas volume, and the time required to collect the gas. Initially, the total moles of offgas $\left(\mathrm{n}_{\text {offgas }}\right)$ were calculated using the volume of gas generated during the collection period and the ideal gas law. The calculation is shown below.

$\mathrm{n}_{\text {offgas }}=\frac{(1 \mathrm{~atm})(10 \mathrm{~mL})\left(\frac{1 \mathrm{~L}}{1000 \mathrm{~mL}}\right)}{\left(0.08206 \frac{\mathrm{L} \mathrm{atm}}{\text { mole K}}\right)(298 \mathrm{~K})}=4.1 \times 10^{-4} \mathrm{moles}$

The moles of $\mathrm{H}_{2}$ ( $\left.\mathrm{n}_{\text {hydrogen }}\right)$ produced during the collection period were calculated by multiplying the total moles of offgas by the adjusted $\mathrm{H}_{2}$ concentration (equation C.3).

$\mathrm{n}_{\text {hydrogen }}=\left(4.1 \times 10^{-4}\right.$ mole $)\left(\frac{0.024 \text { mole } \mathrm{H}_{2}}{\text { mole }}\right)\left(\frac{1 \times 10^{6} \mu \text { mole }}{\text { mole }}\right)=9.8 \mu$ mole $\mathrm{H}_{2}$

The $\mathrm{H}_{2}$ generation rate ( $\left.\mathrm{r}_{\text {hydrogen }}\right)$ was then calculated by dividing the moles of $\mathrm{H}_{2}$ produced during the collection period by the collection period time (equation C.4).

$\mathrm{r}_{\text {hydrogen }}=\frac{9.8 \mu \text { mole } \mathrm{H}_{2}}{120 \min }=0.082 \frac{\mu \text { mole } \mathrm{H}_{2}}{\min }$ 